\title{
Correction to: Influence of Plasma Treatments on the Hemocompatibility of PET and PET $+\mathrm{TiO}_{2}$ Films
}

\author{
lonut Topala ${ }^{1} \cdot$ Nicoleta Dumitrascu $^{1} \cdot$ Valentin Pohoata $^{1}$
}

Published online: 6 June 2020

๑) Springer Science+Business Media, LLC, part of Springer Nature 2020

\section{Correction to: Plasma Chem Plasma Process (2008) 28:535-551 https://doi.org/10.1007/s11090-008-9136-0}

The Editor-in-Chief would like to alert readers that due to an administrative error, the article [1] has been republished in the same journal as [2]. The correct citation for this article should be the original publication [1].

\section{References}

1. Topala I, Dumitrascu N, Pohoata V (2007) Influence of plasma treatments on the hemocompatibility of PET and PET $+\mathrm{TiO}_{2}$ films. Plasma Chem Plasma Process 27:95-112. https://doi.org/10.1007/s1109 0-006-9046-y

2. Topala I, Dumitrascu N, Pohoata V (2008) Influence of plasma treatments on the hemocompatibility of PET and PET $+\mathrm{TiO}_{2}$ films. Plasma Chem Plasma Process 28:535-551. https://doi.org/10.1007/s1109 0-008-9136-0

Publisher's Note Springer Nature remains neutral with regard to jurisdictional claims in published maps and institutional affiliations.

The original article can be found online at https://doi.org/10.1007/s11090-008-9136-0.

Ionut Topala

itopala@plasma.uaic.ro

1 Plasma Physics Laboratory, Faculty of Physics, Alexandru Ioan Cuza University, Blvd. Carol I, No. 11, 700506 Iasi, Romania 